\title{
PROYEKSI PRODUKSI IKAN HASIL TANGKAPAN DI PELABUHAN PERIKANAN SAMUDERA KUTARAJA PROVINSI ACEH
}

\section{PROJECTION OF FISH CATCH PRODUCTION PROJECTION IN OCEAN FISHERMING KUTARAJA ACEH PROVINCE}

\author{
Kurnia $^{1}$, Mustaruddin ${ }^{2}$, Ernani Lubis ${ }^{2}$ \\ ${ }^{1}$ Progam Studi Teknologi Perikanan Laut, \\ ${ }^{2}$ Departemen Pemanfaatan Sumberdaya Perikanan, \\ Fakultas Perikanan dan Ilmu Kelautan, Insitut Pertanian Bogor \\ Korespondensi: kurnia.tpl54.ipb@gmail.com
}

\begin{abstract}
PPS Kutaraja is a very strategic port and is being developed by the Government of Aceh to become the economic center of fisheries. This study aims to analyze the production of captured in PPS Kutaraja and project the production of captured fish for the year (2020-2024). The research was conducted in June-July 2019. The method used was a case study with forecast analysis using a simple linear ranking model and calculating the value of determination and SEE. Based on the analysis, it is known that the development of IHT production in 2012-2018 has increased every year with an average of $17 \%$. Forecasting results for 2020 reached 92.637,85 ton, in 2021 reached 159.162,54 ton, in 2022 it reached 260.598,23, in 2023 it reached 268.820,21 ton, and in 2024 reached 272.978,67 ton. The conclusion is the forecasting of production results has increased very dramatically in the next 5 years.
\end{abstract}

Keywords: fish production, PPS Kutaraja, production projection

\begin{abstract}
ABSTRAK
Pelabuhan Perikanan Samudera (PPS) Kutaraja merupakan pelabuhan yang sangat strategis dan sedang dikembangkan oleh Pemerintah Aceh menjadi pusat ekonomi perikanan. Penelitian ini bertujuan untuk menganalisis produksi Ikan Hasil Tangkapan (IHT) di PPS Kutaraja dan memproyeksikan produksi Ikan Hasil Tangkapan (IHT) untuk tahun (2020-2024). Penelitian dilakukan pada bulan Juni-Juli 2019. Metode yang digunakan adalah studi kasus dengan analisis peramalan menggunakan model regresi linier sederhana dan berpangkat, serta menghitung nilai determinasi dan SEE. Berdasarkan hasil analisis diketahui perkembangan produksi IHT tahun 2012-2018 mengalami peningkatan setiap tahunnya dengan rata-rata mencapai 17\%. Hasil peramalan untuk tahun 2020 mencapai 92.637,84 ton, 2021 mencapai 159.162,54 ton, tahun 2022 mencapai 260.598,23 ton, tahun 2023 mencapai 268.820,21 ton, dan pada tahun 2024 mencapai $272.978,67$ ton. Kesimpulannya adalah peramalan hasil produksi mengalami peningkatan yang sangat drastis dalam kurun waktu 5 tahun kedepan.
\end{abstract}

Kata kunci: Pelabuhan Kutaraja, produksi ikan, proyeksi produksi 


\section{PENDAHULUAN}

Pada beberapa dekade tahun terakhir konsumsi ikan laut mengalami peningkatan yang sangat tinggi. Kenaikan ini dikarenakan terjadi peningkatan kebutuhan akan konsumsi ikan laut oleh masyarakat Indonesia. Ansori (2018) menjelaskan bahwa data konsumsi ikan pada tahun 2014 mencapai 38,14 kg/kapita dan pada tahun 2017 meningkat yaitu mencapai $53,28 \mathrm{~kg} /$ kapita. Peningkatan gemar makan ikan menyebabkan permintaan produksi ikan hasil tangkapan yang cukup tinggi. Produksi perikanan menurut statistik perikanan tangkap pada tahun 2016 mencapai 6.580.191 ton.

Peranan pelabuhan sebagai pusat aktivitas dan sentra produksi ikan hasil tangkapan harus terpenuhi adalah fasilitas dan sarana pelabuhan yang memadai. Salah satu pelabuhan perikanan yang memiliki produksi ikan hasil tangkapan yang cukup besar di Aceh adalah Pelabuhan Perikanan Samudera Kutaraja yang termasuk dalam wilayah pengelolaan perikanan WPP 572 dengan status yang sudah over exploited untuk ikan pelagis dan fully exploited bagi ikan demersal. PPS Kutaraja yang terletak di Kota Banda Aceh ini memiliki lokasi yang sangat strategis, yang berhadapan langsung dengan Selat Malaka dan Samudera Hindia. Fajri et al. (2018) juga menyatakan, bahwa PPS Kutaraja berada di lokasi yang dekat dengan lokasi daerah penangkapan ikan (DPI) yang potensial dan berhadapan langsung dengan alur pelayaran internasional. Melihat potensi dari PPS Kutaraja maka pemerintah pusat yang dibantu oleh UPTD PP Kutaraja, Pemerintah Pusat dan Pemerintah Aceh mengambil langkah konkrit yaitu pada tahun 2014 Pelabuhan Perikanan Kutaraja yang lama (PPP Lampulo) ke PPS Kutaraja yang ada sekarang (KKP 2014). Perpindahan pelabuhan ini mengakibatkan peningkatan status pelabuhan yaitu dari pelabuhan perikanan kelas C menjadi kelas A pada tahun 2016.

Perubahan status ini mendorong produksi ikan hasil tangkapan meningkat. UPTD PPS Kutaraja (2019) menyatakan bahwa produksi ikan hasil tangkapan pada tahun 2014 mencapai 8.519,861 ton dan pada tahun 2018 mengalami peningkatan yaitu mencapai 17.640,34 ton. Jenis ikan hasil tangkapan yang didaratkan di PPS Kutaraja merupakan jenis ikan dominan yang bertujuan untuk ekspor, oleh karena itu investor sudah mulai berdatangan untuk melakukan investasi di Pelabuhan Perikanan Samudera (PPS) Kutaraja. Hal ini mengakibatkan Pemerintah Aceh menetapkan PPS Kutaraja sebagai salah satu pusat perekonomian Aceh.

Pelabuhan Perikanan Samudera Kutaraja yang merupakan pusat ekonomi Aceh, hendaknya para pengalola pelabuhan perikanan perlu memproyeksi produksi ikan hasil tangkapan untuk tahun selanjutnya. Syaputra et al. (2015) menjelaskan bahwa proyeksi ini bertujuan untuk mempersiapkan kondisi sarana dan prasarana pelabuhan perikanan pada tahun berikutnya. Sehingga dapat mencegah terjadinya masalah berupa ketidakmampuan pelabuhan dalam menjamin keberlangsungan aktivitasaktivitas yang ada. Berdasarkan hasil wawancara di lapangan, proyeksi produksi ikan hasil tangkapan perlu dilaksanakan di PPS Kutaraja agar dapat mempersiapkan fasilitas yang ada di pelabuhan untuk menghadapi peningkatan produksi yang akan terjadi pada tahun-tahun mendatang. Penelitian ini bertujuan untuk menganalisis perkembangan produksi ikan hasil tangkapan di PPS Kutaraja dan memproyeksikan produksi ikan hasil tangkapan untuk 5 tahun mendatang.

\section{METODE PENELITIAN}

Penelitian ini dilaksanakan pada bulan Juni-Juli 2019 di Pelabuhan Perikanan Samudera (PPS) Kutaraja yang merupakan Unit Pelaksanaan Teknik Daerah (UPTD) PP Kutaraja di Desa Lampulo, Kecamatan Kuta Alam, Kota Banda Aceh, Provinsi Aceh. Data yang dibutuhkan dalam penelitian ini adalah data sekunder yang diambil langsung di Unit Pelaksanaan Teknik Daerah (UPTD) PP Kutaraja, yaitu data produksi ikan hasil tangkapan tahun 20122018, data produksi ikan bulan terakhir dan data jumlah frekuensi pendaratan kapal. Analisis data yang digunakan pada penelitian ini adalah analisis deskriptif kualitatif dan analisis peramalan. Analisis deskriptif kualitatif digunakan untuk menilai perkembangan produksi ikan hasil tangkapan. Sugiyono (2010) menyatakan, analisis deskriptif kualitatif merupakan suatu penelitian yang menggambarkan, membentuk, serta menganalisis suatu kejadian ataupun penelitian yang terkait. Oleh karena itu, analisis ini cocok digunakan untuk menilai perkembangan produksi ikan hasil tangkapan yang ada 
di Pelabuhan Perikanan Samudera (PPS) Kutaraja. Selanjutnya untuk analisis kedua yaitu menggunakan analisis peramalan. Analisis ini memproyeksikan produksi ikan hasil tangkapan tahun 2019-2024. Analisis ini bertujuan untuk memprediksi produksi ikan hasil tangkapan untuk tahun mendatang. Razak dan riksakomara (2017) juga menyatakan, analisis ini umumnya digunakan untuk memprediksi variabel produksi IHT pada tahun-tahun berikutnya.

Proyeksi produksi ikan hasil tangkapan ini menggunakan dua metode yaitu model linear regresi dan polynomial. Metode polynomial menggunakan dua ordo yaitu ordo 2 dan ordo 4. Alasan menggunakan metode ini dikarenakan memiliki nilai eror yang sangat kecil dan juga dapat melihat periode perkembangan produksi secara bertahap. Oleh karena itu, formulasinya adalah sebagai berikut (Neter 1997):

- Model regresi linier sederhana yaitu:

$$
\hat{y}=a+b X 1+e
$$

- Model regresi berpangkat n (polynomial regresi model 2 dan 4) yaitu:

$$
\hat{y}=b 0+b 1 X 1+b 2 X 2+\ldots+b n X n+e
$$

Keterangan:

$a=$ Konstanta

$b=$ Kostanta koefisien regresi

$\hat{y}=$ Prediksi volume hasil tangkapan

$X=$ Rata-rata waktu (tahun dan bulan)

Selanjutnnya dilakukan penentuan nilai deteminasi (R2). Tujuan nilai deteminasi ini untuk mengukur suatu model dalam menganalisis variasi variabel dependen. Selanjutnya melihat koefisien korelasi person $r_{x y}$ hitung sebagai berikut (Thode 2002):

$r_{x y}$ hitung $=\frac{\left(n \sum x y\right)-\left(\sum x \sum y\right)}{\sqrt{\left[\sum\left(n \sum x^{2}\right)-\left(\sum x^{2}\right)\left(n \sum y^{2}\right)-\left(\sum y^{2}\right)\right]}}$

Hipotesis $=$

$\mathrm{HO}=\mathrm{r}_{\mathrm{xy}}=0$ maka tidak ada korelasi antara variabel $\mathrm{x}$ dan variabel $\mathrm{y}$

$\mathrm{HO}=\mathrm{r}_{\mathrm{xy}} \neq 0$ maka ada korelasi antara variabel $\mathrm{x}$ dan variabel $\mathrm{y}$

Keputusan $=$

Jika $\mathrm{r}_{\mathrm{xy}}$ y hitung <= $\mathrm{r}$ tab maka tolak $\mathrm{HO}=$ tidak ada korelasi antara variabel $\mathrm{x}$ dan $\mathrm{y}$ Jika $r_{x y}$ hitung $>=r$ tab maka terima $\mathrm{HO}=$ ada korelasi antara variabel $\mathrm{x}$ dan $\mathrm{y}$

Penentuan nilai SEE dihitung menggunakan rumus sebagai berikut (Neter 1997):

$$
S E E=\sqrt{\frac{\sum_{j}^{m}(\mathrm{yi}-\hat{\mathrm{y}} \mathrm{i})^{2}}{m}}
$$

Keterangan:

$Y i=$ Data aktual pada waktu ke- $j$

$\hat{y} i=$ Data hasil peramalan pada waktu ke- $j$

$j=$ Waktu ke-j dari data yang dihitung penyimpangannya

$m$ = Banyaknya data yang dihitung penyimpangannya

$\hat{Y}=$ Rata-rata data aktual

\section{HASIL DAN PEMBAHASAN}

Proyeksi produksi ikan hasil tangkapan yang perlu dianlisis adalah data produksi ikan hasil tangkapan. Produksi Ikan Hasil Tangkapan dapat dilihat dari beberapa komponen yaitu: 1) volume ikan hasil tangkapan Pelabuhan Perikanan Samudera Kutaraja dan 2) jenis ikan hasil tangkapan yang dominan di PPS Kutaraja. Oleh karena itu tujuan tentang analisis perkembangan produksi ikan hasil tangkapan di PPS Kutaraja adalah sebagai berikut:

\section{Volume ikan hasil tangkapan}

Perkembangan volume produksi ikan hasil tangkapan di suatu pelabuhan perikanan penting untuk dikaji. Hal ini dapat memberikan informasi bagi para pelaku pelabuhan dalam menyesuaikan kapasitas fasilitas pelabuhan, informasi bagi pihak industri pengolahan yang menggunakan bahan baku ikan, serta membantu pihak ilmuawan dalam mengembangkan tujuantujuan lainnya terkait dengan produksi ikan hasil tangkapan. Tabel 1 mempaparkan perkembangan volume produksi ikan hasil tangkapan PPS Kutaraja selama tujuh tahun (2012-2018).

Tabel 1 menunjukkan bahwa volume produksi ikan hasil tangkapan PPS Kutaraja pada periode tahun 20122018 cenderung meningkat dengan ratarata pertumbuhan volume sebesar $18 \%$. Selanjutnya pada tahun 2012 sampai 2013 mengalami peningkatan dari $6.823,16$ ton menjadi $9.041,38$ ton. Namun pada tahun 2014 mengalami penurunan $-6 \%$ atau 
jumlahnya $8.519,86$ ton. Penyebabnya adalah pada tahun 2014 menurut data statistik perikanan, rata-rata nelayan belum melakukan aktivitas bongkar di Pelabuhan Perikanan Kutaraja yang baru, sehingga mengalami penurunan produksi. Sementara itu, volume produksi ikan hasil tangkapan pada tahun 2015 mengalami peningkatan yang cukup besar yaitu $43 \%$ atau $12.154,44$ ton. Hal ini dikarenakan terjadi pergerakan pemindahan aktivitas bongkar muat hasil tangkapan dari pelabuhan lama (PPLampulo) ke PPS Kutaraja oleh pihak pengelola dan pemerintah. Selanjutnya pada tahun 2016 , 2017, hingga 2018 volume produksi ikan hasil tangkapan mengalami perkembangan yang fluktuatif. Volume produksi tahun 2016 mencapai $12.579,92$ ton yaitu meningkat mencapai 4\%, tahun 2017 mengalami peningkatan sebesar $11 \%$ atau mencapai $13.967,99$ ton dan pada tahun 2018 mengalami peningkatan kembali yaitu $26 \%$ atau mencapai $17.640,34$ ton. Naik turunya volume produksi ini kemungkinan pada tahun tersebut jumlah sumber daya ikan di perairan Aceh mengalami naik-turun (Fajri 2018).

\section{Jenis ikan hasil tangkapan}

Volume produksi ikan hasil tangkapan pada tahun 2018 yaitu mencapai 1.7640,34 ton. Jenis ikan hasil tangkapan di PPS Kutaraja bervariasi (UPTD PP Kutaraja 2019). Namun ada lima jenis ikan hasil tangkapan yang dominan yaitu, ikan cakalang (Katsuwonus pelamis), layang (Decapterus), tuna sirip kuning (Tunnus albacares), tongkol lisong (Auxis rochei), dan tongkol krai (Auxis thazard) (Tabel 2).

Tabel 1. Perkembangan volume produksi ikan hasil tangkapan 2012-2018

\begin{tabular}{cccc}
\hline No & Tahun & Produksi (ton) & Peningkatan (\%) \\
\hline 1 & 2012 & $6.823,15$ & - \\
2 & 2013 & $9.041,39$ & $33 \%$ \\
3 & 2014 & $8.519,86$ & $-6 \%$ \\
4 & 2015 & $12.154,44$ & $43 \%$ \\
5 & 2016 & $12.579,92$ & $4 \%$ \\
6 & 2017 & $13.967,96$ & $11 \%$ \\
7 & 2018 & $17.640,44$ & $26 \%$ \\
\hline \multicolumn{5}{c}{ Jumlah }
\end{tabular}

Tabel 2. Jenis ikan hasil tangkapan purse seine dan pancing di PPS Kutaraja 2018

\begin{tabular}{ccccccc}
\hline \multirow{2}{*}{ Bulan } & \multicolumn{5}{c}{ Jenis ikan } & Cakalang \\
\cline { 2 - 5 } (ton) & $\begin{array}{c}\text { Layang } \\
\text { (ton) }\end{array}$ & Madidihang & $\begin{array}{c}\text { Lisong } \\
\text { (ton) }\end{array}$ & $\begin{array}{c}\text { Krai } \\
\text { (ton) }\end{array}$ & Jumlah \\
\hline Jan & 383,93 & 118,29 & 112,33 & 91 & 14,05 & 719,61 \\
Feb & 578,14 & 435,54 & 103,99 & 81,76 & 101,75 & $1.301,19$ \\
Mar & 757,85 & 371,98 & 140,10 & 76,19 & 40,52 & $1.386,63$ \\
Apr & 912,13 & 386,49 & 161,30 & 178,69 & 89,32 & $1.727,94$ \\
Mei & 637,56 & 321,10 & 133,62 & 96,32 & 73,99 & $1.262,55$ \\
Jun & 385,08 & 196,45 & 82,67 & 30,46 & 14,06 & 708,73 \\
Jul & 737,66 & 318,75 & 236,17 & 22,12 & 63,45 & $1.378,15$ \\
Agu & 484,79 & 358,59 & 156,69 & 15,51 & 20,86 & $1.036,46$ \\
Sep & 213,16 & 645,23 & 359,16 & 46,48 & 47,79 & $1.311,83$ \\
Okt & 868,19 & 831,20 & 353,21 & 34,41 & 105,36 & $2.192,39$ \\
Nov & 730,72 & 85,58 & 260,66 & 38,10 & 32,87 & $1.147,93$ \\
Des & 390,24 & 22,08 & 157,22 & 31,39 & 28,28 & $1.147,93$ \\
\hline$\sum$ (kg) & $7.079,44$ & $4.091,30$ & $2.257,14$ & 742,45 & 632,27 & $15.321,34$ \\
\hline
\end{tabular}

Sumber: UPTD PP Kutaraja (data diolah kembali) 
Tabel 2 menunjukkan ikan cakalang (Katsuwonus pelamis) merupakan ikan yang paling dominan didaratkan di PPS Kutaraja pada tahun 2018 mencapai 7.079,45 ton. Hasil pengamatan di lapangan pada bulan Juni-Juli, ikan cakalang selalu tertangkap oleh nelayan PPS Kutaraja. Menurut Habib et al. (2019), suhu permukaan laut Aceh sangat berpengaruh pada penyebaran ikan cakalang. Oleh karena itu, ikan cakalang banyak didaratkan di PPS Kutaraja dan merupakan ikan yang mempunyai nilai ekonomis tinggi.

Selanjutnya jenis ikan yang sering didaratkan di PPS Kutaraja pada tahun 2018 adalah ikan layang (Decapterus) mencapai $4.091,3$ ton, tuna sirip kuning (Tunnus albacares) mencapai $2.257,14$ ton, tongkol lisong (Auxis rochei) mencapai 742,45 ton, dan tongkol krai (Auxis thazard) mencapai 632,27 ton. Syahbandar UPTD PP Kutaraja menyatakan, jenis-jenis ikan ini merupakan ikan bahan utama bagi industi pengolahan ikan di Aceh dan ikan yang paling diminati adalah ikan tuna siprip kuning (Tunnus albacares).

Pada bulan April, Juni, dan Oktober terjadi peningkatan yang fluktuatif, sedangkan pada bulan Juni dan Agustus lima jenis ikan dominan tersebut mengalami penurunan. Salmarika et al. (2019) menyatakan bulan April dan Oktober umumnya produksi ikan hasil tangkapan meningkat karena musim puncak, sedangkan pada bulan Juli dan Agustus adalah musim paceklik. Fajri et al. (2018) juga menyatakan, musim puncak dan musim paceklik ini umumnya dipengaruhi oleh Suhu Permukaan Laut (SPL) dan klorofil yang ada.

\section{Proyeksi hasil tangkapan}

Sebelum memproyeksi produksi ikan hasil tangkapan, maka perlu menentukan model mana yang paling baik dari beberapa model lainnya. Oleh karena itu, PPS Kutaraja mengaplikasikan proyeksi produksi ikan hasil tangkapan untuk tahun sekarang dan lima tahun mendatang menggunakan model linear regresi dan polynomial ordo 2 serta ordo 4. Tahap selanjutnya yaitu membandingkan nilai uji kesalahan dan tahap terakhir menampilkan penyedian produksi ikan hasil tangkapan untuk lima tahun mendatang. Hal ini dapat dipaparkan sebagai berikut:

\section{Model linear regresi}

Model linear regresi merupakan teknik untuk menjelaskan hubungan antara satu titik dengan titik lainnya. Model linear regresi mempuyai satu variabel $\mathrm{x}$ dan memiliki satu variabel y. Wulandari et al. (2018) menyatakan bahwa linear regresi merupakan model proyeksi yang paling sederhana diantara model-model lainnya. Metode proyeksi pada penelitian ini disajikan pada Gambar 1.

Gambar 1 menunjukkan bahwa volume produksi ikan hasil tangkapan yang didaratkan di PPS Kutaraja pada periode tahun 2012-2018 memiliki persamaan regresi yaitu $\hat{y}=10869 \mathrm{x}+$ $542908[\hat{y}=$ prediksi volume produksi ikan hasil tangkapan/tahun di PPS Kutaraja tahun 2012-2018 (ton); $x=\mathrm{i}$ - indeks waktu (tahun; 2012-2018)]. Model linear regresi ini mengambarkan bahwa volume produksi ikan hasil tangkpan sebesar $y=10869$ ton. Hubungan antar variabel produksi hasil tangkapan didaratkan $(\hat{y})$ ton dan indeks waktu $(x)$ bulan adalah masih kurang kuat karena korelasi ( $r$ ) baru mencapai 0,9072.

\section{Model polynomial}

Model polynomial merupakan teknik untuk menjelaskan hubungan antara satu titik dengan titik lainnya dan memiliki persamaan variabel dengan pangkat yang bertingkat. Model polynomial ini memiliki enam ordo (Purnomo et al. 2013). Arti ordo itu sendiri adalah pangkat pada variabel yang ingin ditentukan. Oleh karena itu penelitian ini melihat model polynomial ordo 2 dan ordo 4 (Gambar 2 dan Gambar 3).

Gambar 2 menunjukkan, model polynomial ordo 2 memiliki persamaan regresi yaitu $\hat{y}=32,691 \mathrm{x}^{2}+8417,5 \mathrm{x}+$ $573964[\hat{y}=$ prediksi volume produksi ikan hasil tangkapan/tahun di PPS Kutaraja tahun 2012-2018 (ton); $x=\mathrm{i}$ - indeks waktu (tahun; 2012-2018)]. Metode ini memiliki korelasi baru mencapi 0,675, yang dimana masih kurang kuat dan masih jauh menuju angka satu. Selanjutnya, rata-rata bergerak untuk model polynomial ordo 4 memiliki persamaan regresi yaitu $0,213 \mathrm{x}^{4}-30,109$ $\mathrm{x}^{3}+1373,4 \mathrm{x}^{2}-11.543 \mathrm{x}+6.37854[\hat{y}=$ prediksi volume produksi ikan hasil tangkapan/tahun di PPS Kutaraja tahun 2012-2018 (ton); $x=\mathrm{i}$ - indeks waktu (tahun; 2012-2018)]. Metode ini memiliki korelasi tinggi yaitu mencapai 0,9289 (Gambar 3). 


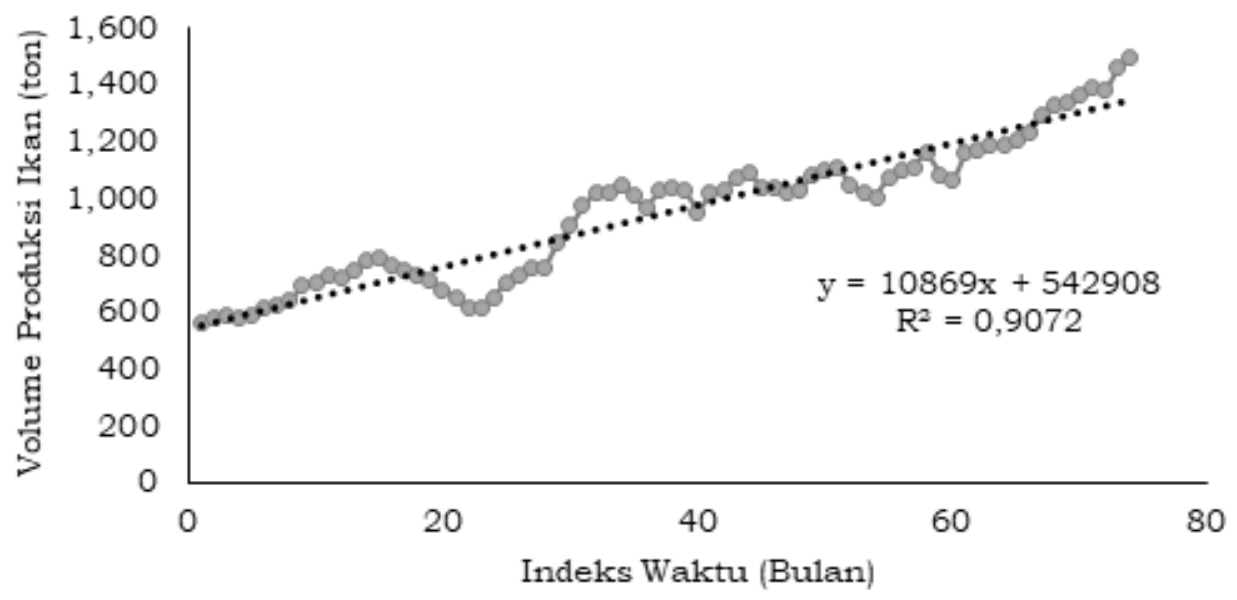

Gambar 1. Model linear regresi

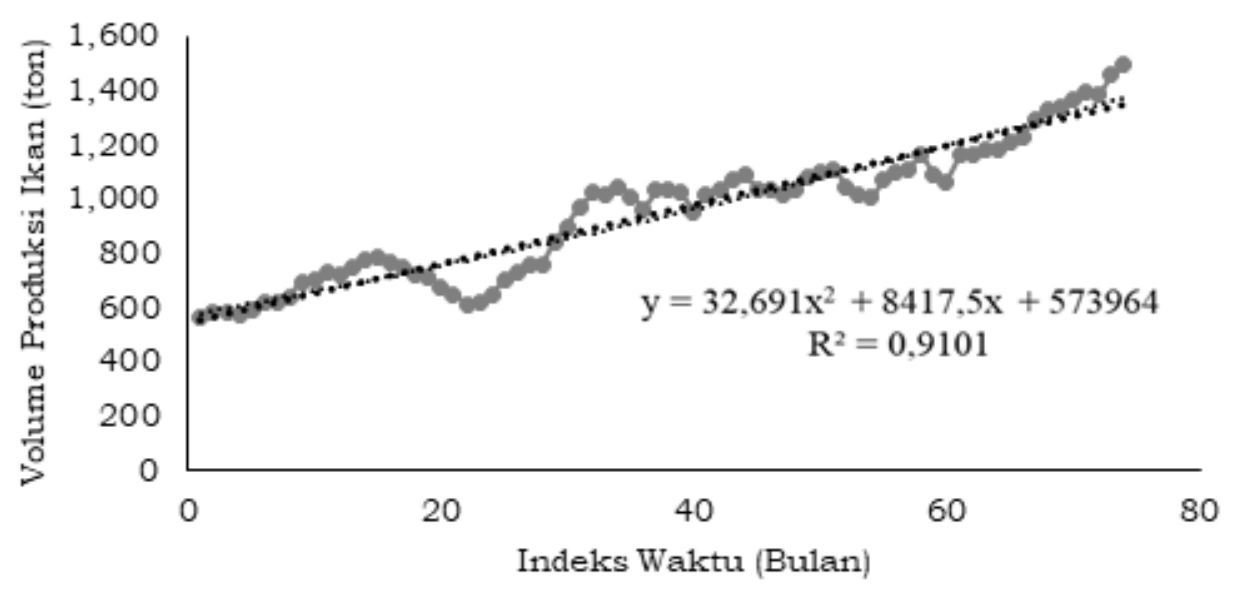

Gambar 2. Model polynomial orde 2

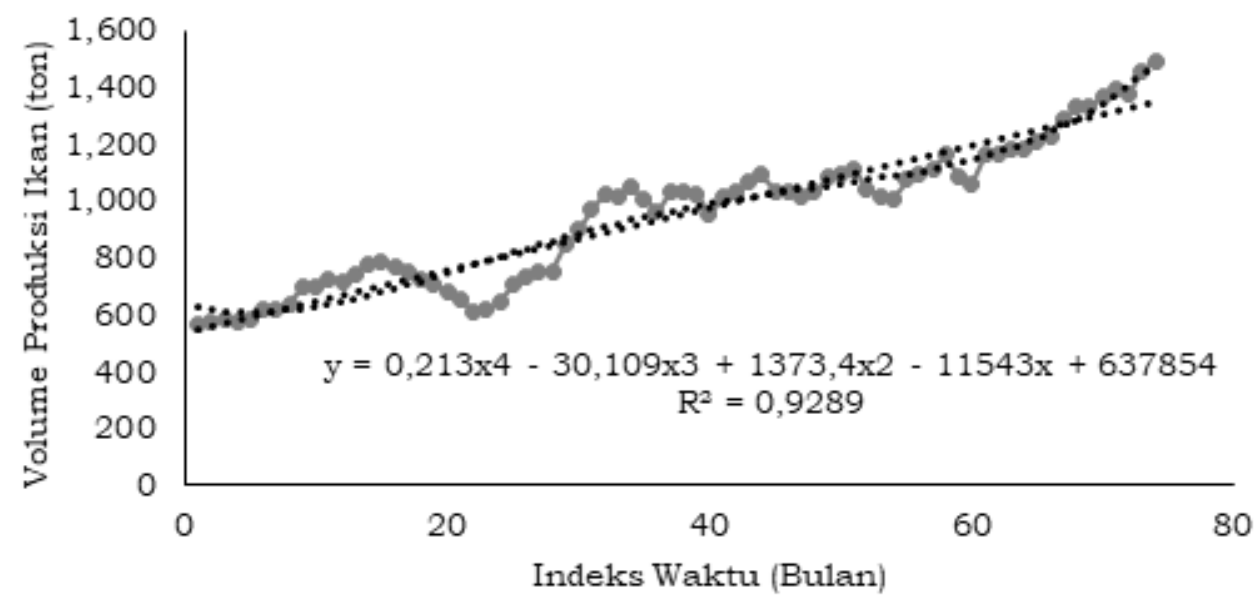

Gambar 3. Model polynomial orde 4

\section{Uji kesalahan}

Sesudah menentukan model dan ordo mana yang terbaik, selanjutnya telah ditentukan uji kesalahan dari ketiga katagori yang sudah disebutkan sebelumnya. Tujuan menentukan uji kesalahan ini adalah melihat seberapa besar error pada data yang sudah diinput. Error pada statistika pendomannya maksimal $10 \%$. Syaputra et al. (2015) menyatakan, semakin besar $R^{2}$ (batas nilai 1) maka data yang error semakin baik. Oleh karena itu proyeksi produksi ikan hasil tangkapan untuk menentuk uji error ini disajikan pada Tabel 3. 


\section{Penyediaan produksi ikan hasil tangkapan untuk tahun selanjutnya}

Hasil dari ketiga metode tersebut menghasilkan korelasi yang hampir mencapai angka 1 yaitu 0,9289 dan memiliki uji error yang paling rendah yaitu mencapai 8,93\%, namun ordo 4 lebih baik. Hasil tersebut sesuai menurut Purnomo et al. (2013) dan Syaputra et al. (2015) bahwa uji kesalahan untuk memproyeksi ikan hasil tangkapan yang baik adalah $<10 \%$ dan nilai korelasi hampir mendekati angka satu. Oleh karena itu, model polynomial ordo 4 sangat cocok digunakan dalam pernyediaan produksi ikan hasil tangkapan untuk lima tahun selanjutnya di PPS Kutaraja (Gambar 4).

Gambar 4 menunjukkan bahwa tahun 2020 produksi ikan hasil tangkapan akan diproyeksi mencapai 92.637,84 ton, tahun 2021 diproyeksi mencapai
159.162,54 ton, proyeksi produksi IHT tahun 2022 mengalami kenaiak yang cukup tinggi yaitu mencapai 260.598,22 ton, tahun 2023 mengalami peningkatan kembali yaitu mencapai 268.8820,21 ton dan tahun terakhir proyeksi mencapai $272.978,67$ ton.

Menurut KKP (2018), jumlah Sumber Daya Ikan (SDI) di perairan Aceh mencapai 292,63 ribun ton. Pada tahun 2024 hasil proyeksi produksi ikan hasil tangkapan sudah mendekati dengan jumlah Sumber Daya Ikan (SDI) di perairan Aceh yaitu 272.978,67 ton. Oleh karena itu, Pemerintah Aceh yang dibantu oleh Pemerintah Pusat mengelola perikanan tangkap dari segi alat tangkap dan kapal penangkapan yang ada. Saran bagi pengelola PPS Kutaraja membuat strategi tentang peningkatan kapasitas fasilitas untuk setiap tahunnya, hal ini diharapkan bisa mengatasi kenaikan produksi ikan hasil tangkapan yang terlalu extreme.

Tabel 3. Menentukan data error

\begin{tabular}{|c|c|c|c|c|}
\hline Model dan Ordo & $\mathbf{R}^{2}$ & $\mathbf{r}$ & SEE & Kesimpulan $\mathbf{r}$ \\
\hline Linear regresi & 0,9072 & 0,95 & $9,68 \%$ & $\begin{array}{l}\text { Errornya sudah cukup rendah dari } \\
\text { sebelumnya }\end{array}$ \\
\hline Polynomial Orde 2 & 0,9072 & 0,95 & $9,66 \%$ & $\begin{array}{l}\text { Errornya sudah cukup rendah dari } \\
\text { sebelumnya }\end{array}$ \\
\hline Polynomial Orde 4 & 0,9289 & 0,964 & $8,93 \%$ & $\begin{array}{l}\text { Errornya sudah cukup rendah dari } \\
\text { sebelumnya }\end{array}$ \\
\hline
\end{tabular}

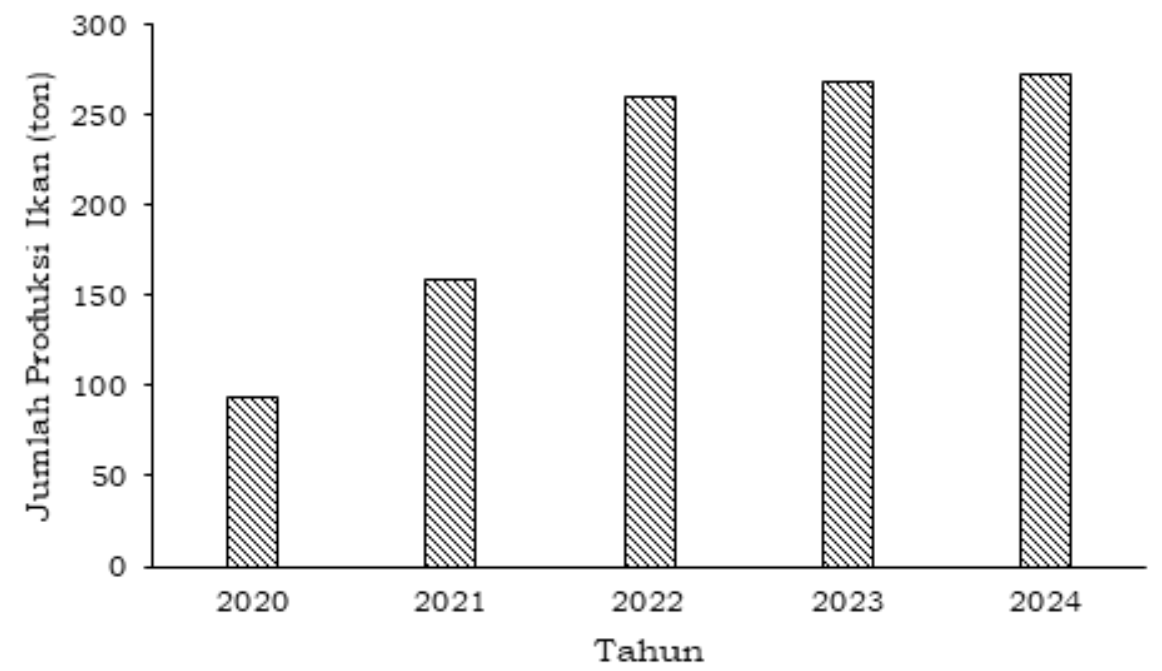

Gambar 4. Proyeksi produksi ikan hasil tangkapan tahun 2019-2024 


\section{KESIMPULAN DAN SARAN}

\section{Kesimpulan}

yaitu:

Penelitian ini dapat disimpulkan

1. Pada tahun 2012 jumlah produksi ikan hasil tangkapan adalah 6.823,16 ton, tahun 2013 adalah 9.041,39 ton, tahun 2014 adalah $8.519,86$ ton, tahun 2015 adalah $12.154,44$ ton, tahun 2016 adalah $12.579,99$ ton, tahun 2017 adalah 13.967,99 ton, dan tahun 2018 adalah $17.640,34$ ton. Ikan yang dominan didaratkan di PPS Kutaraja adalah ikan cakalang (Katsuwonus pelamis), layang (Decapterus), tuna sirip kuning (Tunnus albacares), tongkol lisong (Auxis rochei), serta tongkol krai (Auxis thazard).

2. Penentuan proyeksi produksi ikan hasil tangkapan menggunakan model polynomial ordo 4. Hasil proyeksi produksi ikan hasil tangkapan, pada tahun 2020 adalah 92.637,85 ton, tahun 2021 adalah 159.162,54 ton, tahun 2022 adalah 260.598,2 ton, tahun 2023 adalah 268.820,21 ton, dan tahun 2024 adalah 27.978,67 ton.

\section{Saran}

Berdasarkan penelitian yang sudah dilakukan, saran yang diberikan adalah perlu mengelola pelabuhan secera efektif, jika proyeksi produksi ikan hasil tangkapan meningkat dan pengolahan perikanan tangkapan semakin meningkat.

\section{UCAPAN TERIMA KASIH}

Penulis mengucapkan terimakasih yang sebesar-besarnya kepada Unit Pelaksanaan Teknik Daerah (UPTD) PPS Kutaraja dan semua pihak yang telah membantu dalam penelitian ini.

\section{DAFTAR PUSTAKA}

[KKP] Kementerian Kelautan dan Perikanan. 2014. Peraturan Menteri Kelautan dan Perikanan nomor 45 tahun 2014 Tentang Rencana Induk Pelabuhan Nasional (ID): KKP. http://jdih.kkp. go.id.

[KKP] Kementerian Kelautan dan Perikanan. 2018. Produktivitas Perikanan
Indonesia. https://kkp.go.id/wpcontent/uploads / 2018/01/KKPDirjen-PDSPKP-FMB-Kominfo-19Januari-2018.pdf. [23 Oktober 2019].

Ansori M. 2018. KKP Nyatakan Angka Konsumsi Ikan 2018 Lampaui Target. http://www.neraca.co.id/. [23 Oktober 2019].

Fajri I, Mustarrudin, Baskoro MS. 2018. Pengaruh Faktor Teknis dan Lingkungan terhadap Kinerja Perikanan Purse Seine di Perairan Lampulo Provinsi Aceh. Albacore. 2(2): 135-144.

Habib MEY, Nofrizal, Mubarak. 2019. Sebaran SPL Kaitannya dengan Hasil Tangkapan Ikan Cakalang (Katsuwonus pelamis) di Perairan Aceh. Marine Fisheries. 10(1): 11-22.

Neter J. 1997. Model Linear Terapan Diterjemahkan oleh Bambang Sumantri. Bogor (ID): IPB Press.

Purnomo J, Koesuma S, Yunianto. 2013. Pemisahan Anomial RegionalResidual pada Metode Gravitasi Menggunakan Metode Moving average, polynomial, dan inversion. Indonesia Journal of Applied Physics. 3(1): 10-20.

Razak MA, Riksakomara E. 2017. Peramalan Jumlah Produksi Ikan dengan Menggunakan Backpropagation Neural Netrwor (Studi Kasus: UPTD Pelabuhan Perikanan Banjarmesin). Jurnal teknik ITS. 6(1):142-148.

Salmarika, Taurusman AA, Wisudo SH. 2019. Status Pengelolaan Sumberdaya Ikan Tongkol di Perairan Samudera Hindia Berbasis Pendaratan Pukat Cicin di Pelabuhan Perikanan Samudera Lampulo, Aceh: Suatu Pendekatan Ekosistem. Jurnal Penelitian Perikanan Indonesia. 24(4): 263-272.

Sugiyono. 2010. Metode Penelitian Pendidikan Pendekatan Kuantitatif, Kualitatif, dan R\&D. Bandung (ID): Alfabeta.

Syaputra F, Pane AB, Lubis E, Iskandar BH. 2015. Kebutuhan Fasilitas Pokok Pelabuhan Perikanan Pantai Lampulo 15 Tahun Mendatang. Marine Fisheries. 6(1): 33-43.

Syahbandar Perikanan PPS Lampulo. 2019. Data Jumlah Armada Penangkapan di PPS Lampulo dari Tahun 2012 sampai 2016. Lampulo: Syahbandar Perikanan PPS Lampulo. 
Thode JRH. 2002. Testing for Normality. New York (ID): Merces Dekker.

Wulandari SA, Prasetyanto WA, Tjahyono R. 2018. Perbandingan Forecasting Metode Regresi Non-Linear Polinomial dengan Logika Fuzzy pada Pemetaan Potensi Bisnis Lampulo Berbasis Reduce, Reuse, dan Recycle. ABDIMASKU. 1(2): 7179 . 